\title{
Ulcerative Colitis: Are We Neglecting Its Progressive Character?
}

\author{
Paulo Massinha $^{a}$ Francisco Portela $^{a}$ Sara Campos ${ }^{a}$ Gabriela Duque ${ }^{b}$ \\ Manuela Ferreira $^{a}$ Sofia Mendes ${ }^{a}$ Ana Margarida Ferreira ${ }^{a}$ Carlos Sofia $^{a}$ \\ Luís Toméa

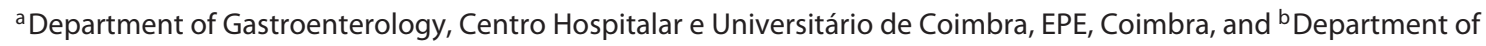 \\ Gastroenterology, Hospital Distrital da Figueira da Foz, EPE, Figueira da Foz, Portugal
}

\section{Keywords}

Ulcerative colitis · Disease progression · Inflammatory bowel disease $\cdot$ Colon $\cdot$ Prognosis

\section{Abstract}

Introduction: Ulcerative colitis (UC) is a chronic disease but its progressive character, with structural damage, is insufficiently studied. Objectives: To analyze a group of patients without referral bias, regarding its clinical course, the morphological damage, and functional status. Methods: We evaluated UC patients diagnosed between January 1, 2000 and December 31, 2004, living in the direct referral area of the hospital and determined the medication use, colectomy rate, structural damage ("lead pipe," stenosis, pseudopolyps, fibrous bridges), and anorectal function (prospective evaluation with the Cleveland Clinic Incontinence Score [CCIS] and the Fecal Incontinence Quality of Life Scale). Results: We identified 104 patients, 47\% female, with a mean age at diagnosis of $38 \pm 17$ years, $24 \%$ with proctitis, $57 \%$ with left colitis, and $19 \%$ with pancolitis. In 3 patients, it was not possible to obtain follow-up data. Of the studied patients, $56 \%$ needed corticosteroid therapy, 38\% immunosuppressants, and $16 \%$ anti-tumor necrosis factors (anti-TNFs). After a mean follow-up of $13 \pm 2$ years, we found structural damage in 25 patients (24\%): $5 \%$ with proctocolectomy, $15 \%$ with "lead pipe," $16 \%$ with pseudopolyps, and 3\% with stenosis and fibrous bridges. Reference to functional anorectal disorders was identified in $49 \%$, mostly previous and self-limited episodes of incontinence, but including persistent incontinence in $10 \%$ (CCIS $8 \pm 4.8$ ). There was an increased incidence of structural damage and anorectal dysfunction in patients who needed corticosteroid therapy ( $p=0.001)$, immunosuppressants $(p<0.001)$, and anti-TNFs $(p=0.002)$ and an association of structural damage with anorectal dysfunction $(p<0.001)$. There was no association between age and anorectal dysfunction, including incontinence episodes. Conclusions: $\mathrm{UC}$ is a disease with structural and functional consequences in a significant subset of patients. This should be incorporated when defining the therapeutic strategy.

\footnotetext{
(c) 2017 Sociedade Portuguesa de Gastrenterologia Published by S. Karger AG, Basel
}

\section{Colite ulcerosa: estamos a desvalorizar o seu caráter progressivo?}

\section{Palavras Chave}

Colite ulcerosa $\cdot$ Progressão da doença · Doença inflamatória intestinal · Cólon · Prognóstico

\section{KARGER}

E-Mail karger@karger.com www.karger.com/pjg
(C) 2017 Sociedade Portuguesa de Gastrenterologia Published by S. Karger AG, Basel Karger Open access

This article is licensed under the Creative Commons AttributionNonCommercial-NoDerivatives 4.0 International License (CC BYNC-ND) (http://www.karger.com/Services/OpenAccessLicense) Usage and distribution for commercial purposes as well as any distribution of modified material requires written permission.
Dr. Paulo Massinha

Centro Hospitalar e Universitário de Coimbra, EPE

Praceta Prof. Mota Pinto

PT-3000-075 Coimbra (Portugal)

E-Mail massinha@iol.pt 


\section{Resumo}

Introdução: A colite ulcerosa (CU) é uma doença crónica mas o seu carácter progressivo, com danos estruturais, encontra-se insuficientemente estudado. Objetivos: Analisar um grupo de doentes, sem viés de referenciação, quanto ao percurso clínico, aos danos morfológicos e ao estado funcional. Métodos: Avaliaram-se os doentes com diagnóstico de CU estabelecido entre 01-01-2000 e 3112-2004, com residência na área de referenciação directa do hospital, tendo-se determinado a medicação usada, a taxa de colectomia, os danos estruturais ("cano de chumbo", estenoses, pseudopolipos, pontes fibrosas) ou funcionais ano-rectais (avaliação prospectiva com Cleaveland Clinic Incontinence Score, CCIS e Fecal Incontinence Quality of Life, FIQL). Resultados: Identificaram-se 104 doentes, $47 \%$ do sexo feminino, idade média no diagnóstico de $38 \pm 17$ anos, proctite $24 \%$, colite esquerda $57 \%$, pancolite 19\%. Em 3 doentes não foi possível obter dados de seguimento. Dos doentes estudados $56 \%$ tiveram necessidade de corticoterapia, 38\% de imunossupressores e $16 \%$ de anti-TNFs. Após um seguimento médio de $13 \pm 2$ anos, encontraram-se danos estruturais em 25 doentes (24\%), protocolectomia em 5\%, "cano de chumbo" 15\%, pseudopolipos $16 \%$ e estenoses e pontes fibrosas $3 \%$. Verificamos referência a disfunção ano-rectal em 49\% (maioritariamente episódios prévios e autolimitados de incontinência) mas incluindo incontinência persistente em $10 \%$ (CCIS $8 \pm 4.8$ ). Verificou-se uma incidência aumentada de danos estruturais e disfunção ano-rectal nos doentes com necessidade de corticoides $(p=0.001)$, imunossupressores $(p<0.001)$ e anti-TNF $(p=0.002)$ e uma relação entre os danos estruturais e a disfunção ano-rectal $(p<0.001)$. Não existiu associação entre a idade e a disfunção ano-rectal, incluindo episódios de incontinência. Conclusões: A CU é uma doença com consequências estruturais e funcionais num subgrupo significativo de doentes. Este facto deve ser integrado na definição da estratégia terapêutica.

(C) 2017 Sociedade Portuguesa de Gastrenterologia Publicado por S. Karger AG, Basel

\section{Introduction}

Currently, the treatment paradigm for Crohn disease (CD) is changing to an earlier, more aggressive treatment [1], with the objective of inducing "mucosal healing" [2]. With this approach, clinicians aim to prevent or retard progression to permanent bowel damage [3]. Nevertheless, despite all studies, it is unknown whether ulcerative colitis (UC) has the same natural history of progression to irreversible bowel damage as does $\mathrm{CD}$, and much less whether an earlier, more aggressive treatment could alter this tendency.

In the literature, there is evidence that chronic UC may extend proximally and, as $\mathrm{CD}$, may also be complicated by structural and functional damage beyond the mucosal layer $[4,5]$, leading to strictures, pseudopolyposis, bridging fibrosis, dysmotility, anorectal incontinence, and possibly impaired permeability $[6,7]$. However, the true prevalence and importance of these later complications in clinical practice are unknown.

Until now, the key endpoints of natural history studies of UC have been colectomy rates, cancer, disease activity, and disease extension. The damaging consequences of persisting inflammation in the colonic function have not been effectively studied. Being a mucosal illness, UC is not typically accompanied by the stricturing and fistulizing complications that can be seen in CD; therefore, there is an inclination among physicians to consider it a less progressive disease. This approach results in a hesitancy to initiate more potent treatments earlier in the progression of the disease, even if this approach has been shown to have better outcomes $[8,9]$.

The aim of this study was to analyze a group of UC patients diagnosed between January 1, 2000 and December 31,2004 , regarding the clinical course, the morphological damage, and functional status.

\section{Patients and Methods}

A total of 633 consecutive patients with UC were under followup in a tertiary referral center by November 2016. Clinical history, demographics, medication use, colectomy rate, and endoscopic/ imagiologic results ("lead pipe," stenosis, pseudopolyp, fibrous bridges) were recorded in a prospectively maintained database.

In this study, we retrospectively selected all patients diagnosed between January 1, 2000 and December 31, 2004, living in the direct referral area of the hospital (serving a defined population of 509,000 inhabitants).

Individuals included in the study were diagnosed with UC based on clinical, endoscopic, radiological, and histological findings. The anatomic distribution of the disease at the time of diagnosis and during clinical follow-up was determined by endoscopic evaluation and classified according to the Montreal classification.

Although most patients did not undergo a barium enema, where the term "lead pipe colon" was primarily applied, the patients with a shortened, stiff and narrowed colon, with diffuse loss of haustration in colonoscopy, were classified as having this condition.

The functional anorectal disorder evaluated was fecal incontinence, defined as uncontrolled passage of fecal material recurring for 3 months. Leakage of flatus alone was not characterized as fecal 
incontinence, partly because of the difficulty to define when passage of flatus is abnormal. Strictures were defined as areas of constant narrowing, noted either by surgery, radiology, or endoscopy.

After obtaining informed consent, sociodemographic and clinical parameters were retrieved from all patients. Sociodemographic data included patient age and gender. Clinical data included the history of inflammatory bowel disease (date of diagnosis, disease activity, endoscopic/imagiologic results), associated comorbidities, smoking history, surgical background, previous and current treatment for inflammatory bowel disease (aminosalicylates, corticosteroids, immunomodulators or biologic therapy with anti-tumor necrosis factors [anti-TNFs]).

We performed a prospective evaluation using the Cleveland Clinic Incontinence Score (CCIS) and the Fecal Incontinence Quality of Life Scale for anorectal functional status evaluation, through a telephone interview. The CCIS takes into account the frequency of incontinence and the extent to which it alters a person's life in 5 questions assessing type of incontinence (solid, liquid, gas, wears pad, lifestyle alteration) and the frequency with which a type of incontinence occurs is rated on a scale from 0 (never) to 4 (always). The sum of the frequencies is added to yield a total score that can range from 0 to 20 , with higher scores indicating higher levels of incontinence. The Fecal Incontinence Quality of Life Scale is composed of a total of 29 items. These items form 4 scales: lifestyle (10 items), coping/behavior (9 items), depression/ self-perception ( 7 items), and embarrassment ( 3 items). We define persistent incontinence for symptoms with, at least, 1 year of duration. All these tests were applied to patients in a nonactive phase of the disease (less than 3 bowel movements per day without blood or mucus).

Statistical analysis was performed with SPSS 20.0 software (SPSS, Chicago, IL, USA). All continuous variables are listed as mean \pm SD. Mean values between the different groups were compared using the Student $t$ test for continuous variables and categorical data were compared using the $\chi^{2}$ test. All reported $p$ values were two-tailed, and $p$ values of less than 0.05 were considered statistically significant.

\section{Results}

A total of 104 patients diagnosed with UC were included in this analysis; however, in 3 patients it has not been possible to obtain follow-up data. There were 55 men and 49 women (47\%) included in the study, with a male-to-female ratio of 1.1:1. The mean age at diagnosis was $38 \pm 17$ years (range 13-81 years). The follow-up period ranged from 11 to 15 years, with a mean follow-up period of 13 years. Characteristics of the study population are summarized in Table 1.

At diagnosis, left colon type involvement (Montreal classification E2) was the most common (57\%) and pancolitis (Montreal classification E3) was the least commonly seen extent of the disease (19\%). In $24 \%$ of the patients, proctitis (Montreal classification E1) was observed. Among the proctitis and left-side colon type patients,
Table 1. Clinical characteristics of patients with UC $(n=104)$

\begin{tabular}{ll}
\hline Sex & \\
Men & $55(53 \%)$ \\
$\quad$ Women & $49(47 \%)$ \\
Age at diagnosis, years & $13-81$ \\
$\quad$ Range & 38 \\
$\quad$ Median & \\
Follow-up period, years & $11-15$ \\
$\quad$ Range & 13 \\
$\quad$ Median & \\
Maximum extent of the disease & $18(17 \%)$ \\
$\quad$ Proctitis (E1) & $60(58 \%)$ \\
$\quad$ Left-side colon (E2) & $26(25 \%)$ \\
$\quad$ Total colon (E3) & \\
Smoking & $8(7.7 \%)$ \\
$\quad$ Active & $26(25 \%)$ \\
$\quad$ Former & $70(67 \%)$ \\
$\quad$ No &
\end{tabular}

$12 \%$ presented proximal disease extension during the follow-up period.

There was a statistically significant association between age and extent of the disease $(\mathrm{p}=0.014)$. Individuals who had been diagnosed with UC prior to the age of 40 years had a prevalence of extensive colitis that was $32 \%$ higher than that observed in individuals diagnosed with UC when they were over 40 years of age.

Regarding smoking habits, $8 \%$ of the patients were active smokers, $25 \%$ former smokers, and $67 \%$ nonsmokers.

The majority of our UC patients (92\%) were on 5-aminosalicylic acid therapy. About half of the UC patients (56\%) received steroids for disease management, 37\% azathioprine, and $16 \%$ anti-TNFs. A small percentage of UC patients were treated with cyclosporine (1\%) (Fig. 1).

A total of 5 patients were submitted to a colectomy, 4 for disease activity and 1 for high-grade dysplasia in follow-up biopsies. Stenosis occurred in 3\% of patients. No colon cancer (adenocarcinoma) was noted in our patients. In $15 \%$ of the patients, a "lead pipe" colon was described, in $16 \%$ pseudopolyps, and in $3 \%$ fibrous bridges (Fig. 2). The average time between UC diagnosis and first structural damage report was $5.9 \pm 3.4$ years.

Reference to functional anorectal disorders was identified in $49 \%$, mostly previous and self-limited episodes of incontinence, but including persistent incontinence in $10 \%$ of the patients (CCIS $8 \pm 4.8$ ). Using CCIS, we identified 5 patients with mild incontinence, 4 with moderate, and 1 patient was classified with severe incontinence (Fig. 3). 


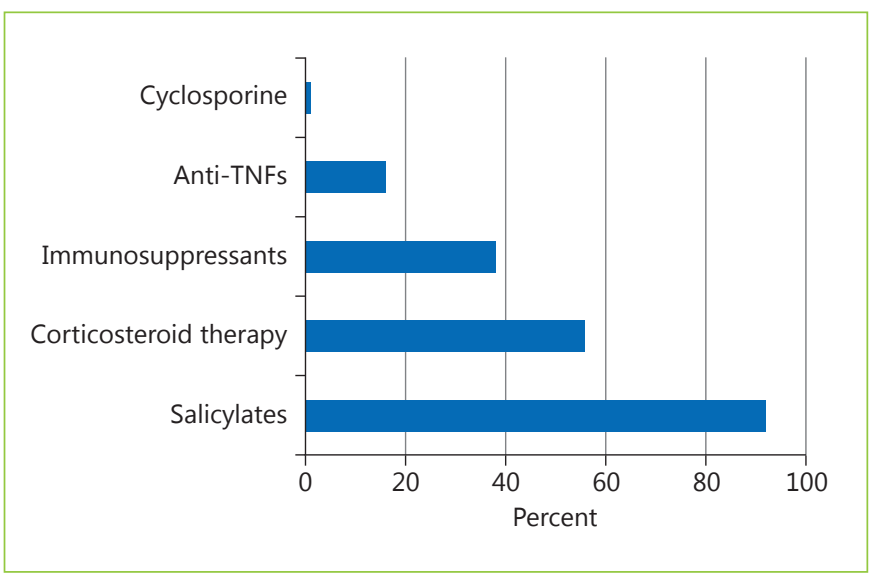

Fig. 1. Medication of the studied patients.

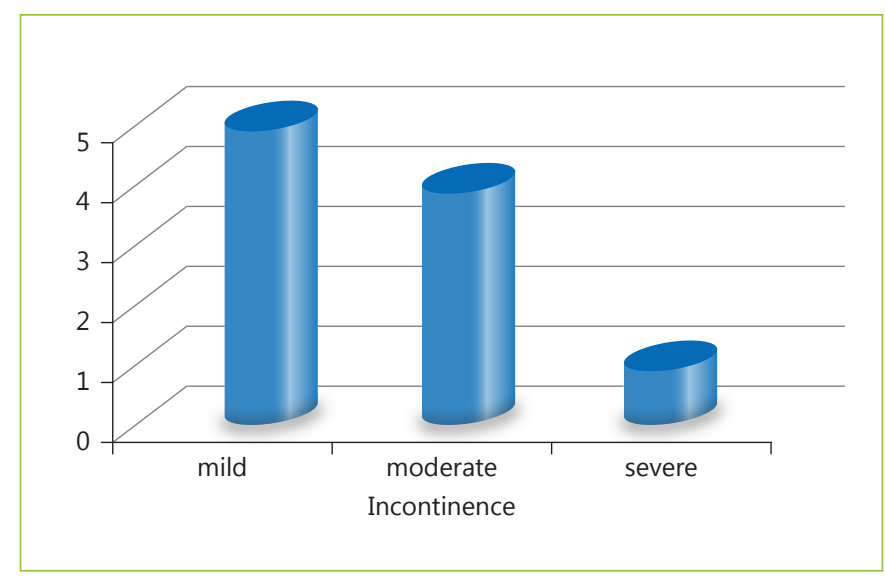

Fig. 3. Incontinence according to the CCIS.

There was an increased prevalence of structural damage and anorectal dysfunction in patients who needed corticosteroid therapy $(p=0.001)$, immunosuppressants $(p<$ $0.001)$, and anti-TNFs $(p=0.002)$ and a positive association between structural damage and anorectal dysfunction $(p<0.001)$. There was no association between age and anorectal dysfunction, including incontinence episodes.

\section{Discussion}

It is unknown if UC has the same inexorable tendency to progress to irreversible bowel damage as $\mathrm{CD}$. There is some evidence that in chronic UC, the disease may be

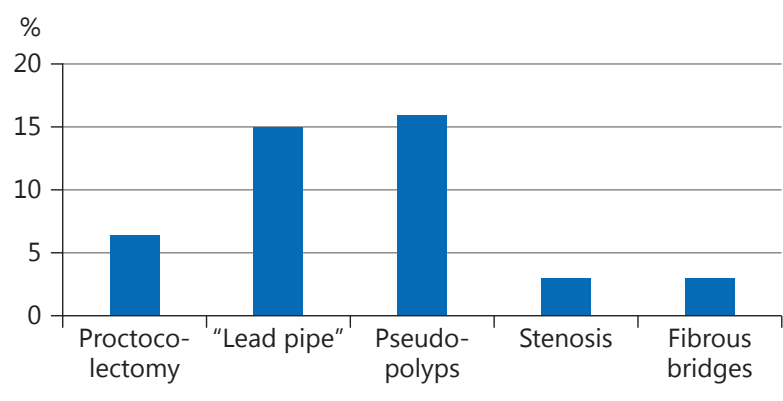

Fig. 2. Morphological damage.

complicated by structural and functional damage beyond the mucosal layer, leading to strictures, pseudopolyposis, bridging fibrosis, dysmotility, and anorectal incontinence $[5,6]$. The true prevalence and relevance of these later complications in clinical practice is unknown; however, they provide the basis to accept that $\mathrm{UC}$, as $\mathrm{CD}$, should be regarded as a progressive disease. Earlier and more aggressive disease control might be a way of avoiding or forestalling these consequences. In this study, we evaluated the long-term disabilities in an UC population, evaluating major consequences of ongoing inflammation in UC, its clinical course, the morphological damage, and functional status.

In our study, we identified 104 patients with UC diagnosed between January 1, 2000 and December 31, 2004, in a population of 509,000, which is contained in the incidence reported in the literature $[10,11]$.

In the modern age of endoscopy, assessment of UC severity and activity is based on medical symptoms and on endoscopic classification of inflammation. In several clinical trials and in clinical practice, therapeutic goals for UC have converted into achieving mucosal healing [12]. Nevertheless, what is considered a healed mucosa by the current endoscopic indexes does not necessarily translate into a healthy mucosa or preservation of gastrointestinal physiology. Atrophic-looking mucosa or mucosa replaced by pseudopolyps can be found in chronic and endstage colitis, and both are, by present endoscopic scores, considered to be healed. Still, these "burned-out" mucosae are possibly not healthy mucosae.

In our study, we found pseudopolyposis in $16 \%$ of patients. These lesions have been theorized to result from 
ulceration, which penetrates across and undermines the muscularis mucosae, therefore permitting sizeable mucosal tags drawn out by the propulsive action of the gut. In a clinical study performed by De Dombal et al. [6], pseudopolyposis was found in 58 of 465 UC patients (12.5\%). A higher prevalence of $48 \%$ was not unexpectedly perceived in a series of colonic resection specimens [13]. Ulceration of these pseudopolyps can cause bleeding and anemia [14-16]. Like pseudopolyposis, another sort of postinflammatory injury is bridging fibrosis. In our study, we observed bridging fibrosis in 3\% of the patients. Van Moerkercke et al. [17] reported the case of a man with UC, in whom bridging fibrosis seemed to be connected with fecal urgency and incontinence even in the absence of endoscopic or histological indication of disease activity.

In dissimilarity with $\mathrm{CD}$, where illness location is rather stable, UC is a dynamic disease with colorectal inflammation extent fluctuating over time, which has significant consequences. The extent of colonic commitment in UC is clinically significant. It has an influence on the requirement and kind of medication, on the severity and activity of the disease, on the degrees of colectomy and hospitalization, and on cancer and mortality risk. 12\% of our proctitis and left colitis colon type patients presented proximal disease extension during the follow-up period. This value was similar to some longitudinal referral center-based and population-based cohorts studies [18] but lower than others that have shown values between 27 and $54 \%[4,19-22]$.

While characteristically connected with $\mathrm{CD}$, strictures can also complicate UC. In our study, stenosis occurred in $3 \%$ of the patients. Edwards and Truelove [23] described benign strictures in $6.3 \%$ of UC cases, and de Dombal et al. [6] in $11.2 \%$. In one of the largest series to date, Gumaste et al. [24] found benign strictures in 3.2\% of UC patients at their referral center. For a long time, it was assumed that UC-related strictures were caused by muscular hypertrophy and thickening of the muscularis mucosae and muscularis propria rather than from fibrosis. However, recent studies have suggested that the cause of colonic stenosis in longstanding UC is fibrosis, possibly induced by inflammatory neutrophils producing b-FGF [25].

Despite the improvement in surgical techniques, colectomy it still considered a dramatic event especially for young patients. The technique may be complicated by postoperative complications such as infections, anastomosis leakage, abscesses, reduced fertility, sexual dysfunction, and small bowel obstructions. Although the general health often improves significantly after removing the sick colon, and the probability of developing colorectal cancer is reduced to a minimum, many patients experience psychological issues with living with an ileostomy or an ileal pouch-anal anastomosis. Furthermore, Hahnloser et al. [26] reported that $70 \%$ of the patients with an ileal pouch experience one or more episodes of pouchitis during a 20 -year period of follow-up. In our study, $5 \%$ of the patients were submitted to a colectomy ( 1 case for dysplasia and 4 for refractory disease).

One disturbing form of dysmotility in UC is compromised anorectal function, leading to urgency, tenesmus, and incontinence. These symptoms are more serious during active and severe inflammation, but it is also known that patients with long-lasting disease may have comparable disorders even when their proctitis is mild or quiescent [27]. In our study, we identified $49 \%$ of patients with functional anorectal disorder (mostly self-limited and previous episodes of incontinence) including persistent incontinence in $10 \%$ of the patients. We observed an association between structural damage and anorectal dysfunction $(p<0.001)$. Pseudopolyps was the lesion with the strongest association ( $p=0.024)$.

No association was observed between the extent of disease and anorectal dysfunction, but a significant association between the extent of the disease and structural damage was identified $(p<0.001)$. No association was observed between duration of the disease and anorectal dysfunction or structural damage. There was an increased incidence of structural damage and anorectal dysfunction in patients who needed corticosteroid therapy $(p=0.001)$, immunosuppressants $(p<0.001)$, and anti-TNFs $(p=$ 0.002 ), showing that patients with the aggressive forms of the disease are the ones with the greatest probability of morphological and functional damage.

Although our definition of inactive disease is not a validated concept, it is accepted worldwide. Nevertheless, we assume that the design of the study does not allow a better evaluation of the disease activity.

\section{Conclusions}

UC is a disease with structural and functional consequences in a significant subset of patients. This important data should be considered when defining the therapeutic strategy.

New studies using operating technical innovations in imaging and in motility should be led, in the future, in order to evaluate the evolution of bowel impairment in $\mathrm{UC}$ and the consequences of disease-modifying agents in preventing it.
Massinha/Portela/Campos/Duque/ Ferreira/Mendes/Ferreira/Sofia/Tomé 


\section{Statement of Ethics}

This study did not require informed consent nor review/approval by the appropriate ethics committee.

\section{Disclosure Statement}

F. Portela received a presenting fee from: AbbVie, Ferring, MSD and Vifor Pharma. The other authors declared no conflicts of interest.

\section{References}

1 Sandborn WJ: Current directions in IBD therapy: what goals are feasible with biological modifiers? Gastroenterology 2008; 135:14421447.

2 Sandborn WJ, Colombel JF, Lomax KG, et al: Achievement of early deep remission is associated with lower rates of weekly dosing for adalimumab treated patients with Crohn's disease: data from extend. Gut 2011;60:A136A137.

3 Pariente B, Cosnes J, Danese S, et al: Development of the Crohn's disease digestive damage score, the Lémann score. Inflamm Bowel Dis 2011;17:1415-1422.

4 Solberg IC, Lygren I, Jahnsen J, et al: Clinical course during the first 10 years of ulcerative colitis: results from a population-based inception cohort (IBSEN study). Scand J Gastroenterol 2009;44:431-440.

5 Moum B, Ekbom A, Vatn MH, et al: Clinical course during the 1st year after diagnosis in ulcerative colitis and Crohn's disease. Results of a large, prospective population-based study in southeastern Norway, 1990-93. Scand J Gastroenterol 1997;32:1005-1012.

6 De Dombal FT, Watts JM, Watkinson G, et al: Local complications of ulcerative colitis: stricture, pseudopolyposis, and carcinoma of colon and rectum. Br Med J 1966;1:1442-1447.

7 Peyrin-Biroulet L, Cieza A, Sandborn WJ, et al: Development of the first disability index for inflammatory bowel disease based on the international classification of functioning, disability and health. Gut 2012;61:241-247.

8 Ochsenkühn T, D’Haens G: Current misunderstandings in the management of ulcerative colitis. Gut 2011;60:1294-1299.

9 Torres J, et al: Ulcerative colitis as a progressive disease: the forgotten evidence. Inflamm Bowel Dis 2012;18:1356-1363.
10 Shivananda S, Leonnard-Jones J, Logan R, et al: Incidence of inflammatory bowel disease across Europe: is there a difference between north and south? Results of the European Collaborative Study on Inflammatory Bowel Disease (EC-IBD). Gut 1996;39:690-697.

11 Magro F, Portela F, Lago P, et al: A pharmacoepidemiological approach to estimate IBD prevalence and incidence in Portugal. J Crohns Colitis 2008;2:35.

12 Silverberg MS, Satsangi J, Ahmad T, et al: Toward an integrated clinical, molecular and serological classification of inflammatory bowel disease: report of a working Party of the 2005 Montreal World Congress of Gastroentetology. Can J Gastroenterol 2005:19(suppl A): 5-36.

13 Kelly JK, Gabos S: The pathogenesis of inflammatory polyps. Dis Colon Rectum 1987; 30:251-254.

14 Kelly JK, Langevin JM, Price LM, et al: Giant and symptomatic inflammatory polyps of the colon in idiopathic inflammatory bowel disease. Am J Surg Pathol 1986;10:420-428.

15 Maggs JRL, Browning LC, Warren BF, et al: Obstructing giant post-inflammatory polyposis in ulcerative colitis: case report and review of the literature. J Crohns Colitis 2008;2:170180.

16 Koga H, Iida M, Aoyagi K, et al: Generalized giant inflammatory polyposis in a patient with ulcerative colitis presenting with protein-losing enteropathy. Am J Gastroenterol 1995;90:829-831.

17 Van Moerkercke W, Deboever G, Lambrecht $\mathrm{G}$, et al: Severe bridging fibrosis of the colon in a man with inflammatory bowel disease. Endoscopy 2007;39(suppl 1):E294.
18 Alkim C, et al: Extension of ulcerative colitis. Turk J Gastroenterol 2011;22:382-387.

19 Farmer RG, Easley KA, Rankin GB: Clinical patterns, natural history, and progression of ulcerative colitis. A long-term follow-up of 1,116 patients. Dig Dis Sci 1993;38:11371146.

20 Langholz E, Munkholm P, Davidsen M, et al: Changes in extent of ulcerative colitis: a study on the course and prognostic factors. Scand J Gastroenterol 1996;31:260-266.

21 Ayres RC, Gillen CD, Walmsley RS, et al: Progression of ulcerative proctosigmoiditis: incidence and factors influencing progression. Eur J Gastroenterol Hepatol 1996;8:555-558.

22 Meucci G, Vecchi M, Astegiano M, et al: The natural history of ulcerative proctitis: a multicenter, retrospective study. Gruppo di Studio per le Malattie Infiammatorie Intestinali (GSMII). Am J Gastroenterol 2000;95:469473.

23 Edwards FC, Truelove SC: Course and prognosis of ulcerative colitis. Gut 1964;5:1-15.

24 Gumaste V, Sachar DB, Greenstein AJ: Benign and malignant colo-rectal strictures in ulcerative colitis. Gut 1992;33:938-941.

25 Yamagata M, Mikami T, Tsuruta T, et al: Submucosal fibrosis and basic fibroblast growth factor-positive neutrophils correlate with colonic stenosis in cases of ulcerative colitis. $\mathrm{Di}$ gestion 2011;84:12-21.

26 Hahnloser D, Pemberton JH, Wolff BG, et al: Results at up to 20 years after ileal pouch-anal anastomosis for chronic ulcerative colitis. $\mathrm{Br}$ J Surg 2007;94:333-340.

27 Rao SS, Read NW, Davison PA, et al: Anorectal sensitivity and responses to rectal distention in patients with ulcerative colitis. Gastroenterology 1987;93:1270-1275. 